Proceedings

\title{
Cumulative Effect of the Aqueous and Ethanolic Extracts of Annona Reticulate and Allium Sativumon Brine Shrimp Lethality Assay ${ }^{\dagger}$
}

\author{
Sandeep Waghulde 1,*, Ashwini Bhoir ${ }^{1}$, Jyoti Gholap ${ }^{1}$, Varsha Patil ${ }^{1}$, Mohan K. Kale ${ }^{1}$ and \\ Vijay R. Patil ${ }^{2}$ \\ 1 Konkan Gyanpeeth Rahul Dharkar College of Pharmacy and Research Institute, Karjat, Raigad 410201, \\ India; ashwinibhoir03@gmail.com (A.B.); jyoti.gholap02@gmail.com (J.G.); \\ varshapatil26051998@gmail.com (V.P.); kalemkpharm@gmail.com (M.K.K.) \\ 2 Hon'ble Loksevak Madhukarrao Chaudhari College of Pharmacy, Faizpur, Jalgaon 425503, India; \\ drvrpatil@gmail.com \\ * Correspondence: sandeepwaghulde@yahoo.com \\ + Presented at the 23rd International Electronic Conference on Synthetic Organic Chemistry, \\ 15 November 2019-15 December 2019; Available online: https:/ecsoc-23.sciforum.net/.
}

Published: 18 November 2019

\begin{abstract}
The present study was conducted to test for in vivo Brine Shrimp Lethality Assay (BSLA) of the Aqueous and ethanolic extracts Annona reticulate Linn. and Allium sativumand correlate cytotoxicity results with known pharmacological activities of the plants. Cytotoxicity was evaluated in terms of LC50 (lethality concentration). Ten nauplii were added into three replicates of each concentration of the plant extract. After $24 \mathrm{~h}$ the surviving brine shrimp larvae were counted and LC50 was assessed. Results showed that the presence of alkaloids, tannins, and flavonoids could be accounted for its cytotoxic properties. In the other hand, studies have shown that the leaf extracts of Alcoholic and aqueous extract of Annona reticulata and bulbs of Allium sativum extracts exhibited cumulative activity when they were combined and compared. Thus, the results on the leaf extracts of Alcoholic and aqueous extract of Annona reticulata and bulbs of Allium sativum exhibited increase in activity support its use in traditional medicine.
\end{abstract}

Keywords: brine shrimp lethality assay; Annona reticulata; Allium sativum; LC50; potent; cytotoxicity

\section{Introduction}

The crushed leaves of A. reticulata are used as poultice on boils, ulcers and abscesses and leaf decoction is used as vermifuge. The tree is not especially attractive. It is erect, with a rounded or spreading crown and trunk 10 to 14 in $(25-35 \mathrm{~cm})$ thick. Height ranges from 15 to $35 \mathrm{ft}(4.5-10 \mathrm{~m})$. The ill-smelling leaves are deciduous, alternate, oblong or narrow-lanceolate, 4 to 8 in $(10-20 \mathrm{~cm})$ long, $3 / 4$ to 2 in $(2-5 \mathrm{~cm})$ wide, with conspicuous veins.

Free radicals have been accused of initiating many serious diseases [1-3]. These free radicals drive oxidative stress and transform the pathophysiological condition of the patient by acting on immune system. It has been known that phenolic and flavonoid compounds of the plant extracts are responsible for antioxidant and antibacterial effects [4-6].

Taking all the above concerns into account, we conducted this study to find out more about A. reticulata leaves. We studied the antioxidant effects with presence of such phytochemical constituents as equivalent to standards in different extracts, the cytotoxic effect, and hence antitumor effect. 


\section{Materials and Methods}

\subsection{Plant Materials}

The leaves of A. reticulata and Allium sativum (bulbs) were collected from regions of Karjat Dist-Raigad, Maharashtra, India in December 2018. Plant materials were authenticated at "The Blatter Herbarium" - St. Xavier's College, Mumbai.

After identification and authentication of the plant, leaves of the plant were collected for the experimental process. The leaves were shade dried, made into coarse powder and the powdered material was initially defatted with petroleum ether and then subjected to cold maceration process for 72-h using 1:1 mixture of methanol and water as solvent to prepare hydro-alcoholic extract of Annona reticulata leave (percentage yield $20.5 \% w / w$ with respect to dried powder). The extract was filtered and concentrated by rotary evaporator. For the preparation of different fractions method was used [7-9].

The sun dried and powdered leaves $(76 \mathrm{~g})$ of A. reticulata were successively extracted in a Soxhlet extractor at elevated temperature using $200 \mathrm{~mL}$ of distilled n-hexane (40-60) ${ }^{\circ} \mathrm{C}$ which was followed by petroleum ether, methanol, and chloroform. All extracts were filtered individually through filter paper and poured on petri dishes to evaporate the liquid solvents from the extract to get dry extracts. The dry crude extracts were weighed and stored in air-tight container with necessary markings for identification and kept in a refrigerator for future investigations.

\subsection{Brine Shrimp Lethality Bioassay}

The extracts, fractions and pure isolated compounds were routinely evaluated in a test for lethality to brine shrimp larvae. Toxicities of compounds were tested at 1, 10, 100 and $1000 \mathrm{ppm}$ in 10 $\mathrm{mL}$ sea-water solutions with $1 \%$ DMSO $(v / v)$. Ten, nauplii were used in each test and survivors counted after $24 \mathrm{~h}$. Three replications were used for each concentration. The blank control is conducted with Distilled water. The lethal concentration for $50 \%$ mortality after $24 \mathrm{~h}$ of exposure, the chronic LC 50 was determined using the probit method, as the measure of toxicity of the extract or fractions. LC 50 values greater than $1000 \mathrm{ppm}$ for plant extracts were considered inactive.

The brine shrimp lethality assay (BSLA) is a simple and inexpensive bioassay used for testing the efficacy of phytochemical present in the plant extracts. The present study determined that the extent of lethality was directly proportional to the concentration of the extract. After $24 \mathrm{~h}$ of observation all the shrimp were survived in the control. Even though, maximum mortalities were observed upto a concentration of $1000 \mu \mathrm{g} / \mathrm{mL}$ and least mortality at $1 \mu \mathrm{g} / \mathrm{mL}$ concentrations. It was observed that in higher concentration of treatment extracts, the shrimps were start dying only after $8 \mathrm{~h}$ and after $24 \mathrm{~h}$ all the shrimps died. The lethality concentration (LC50) was calculated by using probit analysis (Table 1). The LC50 (median lethal concentration) values were calculated by using the regression line obtained by plotting the concentration against the death percentage on a probit scale.

\subsection{Significance of Brine Shrimp Lethality Assay of the Plant}

The evolution of the toxic action of plant extracts is indispensable to consider a treatment safe; it enables the definition of the intrinsic toxicity of the plant, and the effects of acute overdose [10], a cheap and general bioassay that appears capable of detecting a spectrum of bioactivity present in crude extract is the brine shrimp lethality test. The lethality of the test sample in a simple zoological organism like the brine shrimp (Artemia salina) has been utilised by many researchers and has proven to be a useful tool in screening various chemical compounds found in various bioactivities. In this study, it was observed combined aqueous and alcoholic fractions of Annona reticulate and Allium sativum extract exhibited the highest brine shrimp cytotoxic activity.

The combined aqueous and alcoholic fractions of leaves of Annona reticulate and bulbs extracts of Allium sativum exhibited a concentration-dependent cytotoxic activity in brine shrimp and is considered containing active or potent components, brine shrimp lethality assay is inadequate in determining the mechanism of action of the bioactive substances in the plant, but it is useful in 
providing a preliminary screen that can be supported by a more specific bioassay, once the active compound has been isolated [11-14].

Table 1. \% Mortality of shrimp nauplii after treating with Alcoholic and aqueous extract of Annona reticulate and Allium sativum.

\begin{tabular}{|c|c|c|c|c|c|c|c|c|}
\hline \multirow{2}{*}{$\begin{array}{c}\text { Plant Methanolic } \\
\text { Extracts }\end{array}$} & \multirow{2}{*}{$\begin{array}{c}\text { Concentration (ppm } \\
\text { or } \mu \mathrm{g} / \mathrm{mL} \text { ) }\end{array}$} & \multicolumn{3}{|c|}{$\begin{array}{c}\text { Number of Surviving } \\
\text { Nauplii (after } 24 \text { h) }\end{array}$} & \multirow{2}{*}{$\begin{array}{l}\text { Total Number of } \\
\text { Nauplii Survivors }\end{array}$} & \multirow[t]{2}{*}{$\%$ Mortality } & \multirow{2}{*}{$\begin{array}{c}\mathrm{LC}_{50} \\
(\mu \mathrm{g} / \mathrm{mL})\end{array}$} & \multirow[t]{2}{*}{ Graph } \\
\hline & & T1 & T2 & T3 & & & & \\
\hline \multirow{4}{*}{$\begin{array}{l}\text { Control } \\
\text { (Distilled water) }\end{array}$} & 1 & 10 & 10 & 9 & 29 & $96 \%$ & \multirow{4}{*}{372.846} & \multirow{4}{*}{ Figure 1} \\
\hline & 10 & 10 & 9 & 10 & 29 & $96 \%$ & & \\
\hline & 100 & 8 & 10 & 10 & 28 & $93 \%$ & & \\
\hline & 1000 & 10 & 10 & 10 & 30 & $100 \%$ & & \\
\hline \multirow{4}{*}{$\begin{array}{l}\text { Standard } \\
\text { (Vincristine } \\
\text { sulphate) }\end{array}$} & 1 & 0 & 0 & 0 & 0 & $100 \%$ & \multirow{4}{*}{0.00} & \multirow{4}{*}{---- } \\
\hline & 10 & 0 & 0 & 0 & 0 & $100 \%$ & & \\
\hline & 100 & 0 & 0 & 0 & 0 & $100 \%$ & & \\
\hline & 1000 & 0 & 0 & 0 & 0 & $100 \%$ & & \\
\hline \multirow{4}{*}{$\begin{array}{l}\text { Annona reticulata } \\
\text { (Alcoholic) }\end{array}$} & 1 & 10 & 10 & 10 & 30 & $0 \%$ & \multirow{4}{*}{24.162} & \multirow{4}{*}{ Figure 2} \\
\hline & 10 & 6 & 8 & 7 & 22 & $73 \%$ & & \\
\hline & 100 & 3 & 2 & 3 & 8 & $27 \%$ & & \\
\hline & 1000 & 1 & 0 & 0 & 1 & $3.3 \%$ & & \\
\hline \multirow{4}{*}{$\begin{array}{l}\text { Annona reticulata } \\
\text { (Aqueous) }\end{array}$} & 1 & 10 & 10 & 10 & 30 & $0 \%$ & \multirow{4}{*}{18.923} & \multirow{4}{*}{ Figure 3} \\
\hline & 10 & 8 & 6 & 6 & 20 & $66.6 \%$ & & \\
\hline & 100 & 3 & 2 & 5 & 10 & $33.3 \%$ & & \\
\hline & 1000 & 0 & 1 & 0 & 1 & $3.3 \%$ & & \\
\hline \multirow{4}{*}{$\begin{array}{l}\text { Allium sativum } \\
\text { (Alcoholic) }\end{array}$} & 1 & 5 & 7 & 7 & 19 & $37 \%$ & \multirow{4}{*}{10.840} & \multirow{4}{*}{ Figure 4} \\
\hline & 10 & 4 & 4 & 3 & 11 & $63 \%$ & & \\
\hline & 100 & 0 & 0 & 0 & 0 & $100 \%$ & & \\
\hline & 1000 & 0 & 0 & 0 & 0 & $100 \%$ & & \\
\hline \multirow{4}{*}{$\begin{array}{l}\text { Allium sativum } \\
\text { (Aqueous) }\end{array}$} & 1 & 6 & 4 & 5 & 21 & $70 \%$ & \multirow{4}{*}{8.180} & \multirow{4}{*}{ Figure 5} \\
\hline & 10 & 2 & 3 & 3 & 4 & $13.3 \%$ & & \\
\hline & 100 & 1 & 1 & 0 & 2 & $6.6 \%$ & & \\
\hline & 1000 & 0 & 0 & 0 & 0 & $100 \%$ & & \\
\hline \multirow{4}{*}{$\begin{array}{l}\text { Annona reticulate } \\
\text { and } \\
\text { Allium sativum } \\
\text { (1:1) Alcoholic } \\
\text { extracts }\end{array}$} & 1 & 3 & 5 & 4 & 12 & $40 \%$ & \multirow{4}{*}{129.257} & \multirow{4}{*}{ Figure 6} \\
\hline & 10 & 4 & 5 & 5 & 17 & $56.6 \%$ & & \\
\hline & 100 & 3 & 2 & 2 & 4 & $13.3 \%$ & & \\
\hline & 1000 & 1 & 1 & 0 & 2 & $0.03 \%$ & & \\
\hline Annona reticulate & 1 & 3 & 3 & 5 & 12 & 40 & & \\
\hline and & 10 & 5 & 4 & 4 & 14 & 46.6 & & \\
\hline Allium sativum & 100 & 1 & 1 & 3 & 5 & $16.6 \%$ & 93.482 & Figure 7 \\
\hline $\begin{array}{l}\text { (1:1) Aqueous } \\
\text { extracts }\end{array}$ & 1000 & 0 & 0 & 0 & 0 & $100 \%$ & & \\
\hline
\end{tabular}

Cytotoxocity of Control

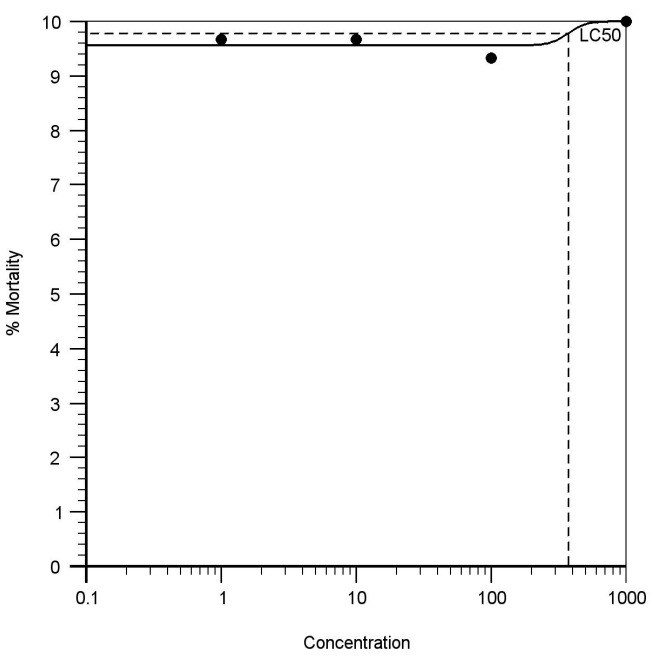

Figure 1. Cytotoxicity of Control. 
Cytotoxocity of Annona reticulata (Alcoholic Ext)

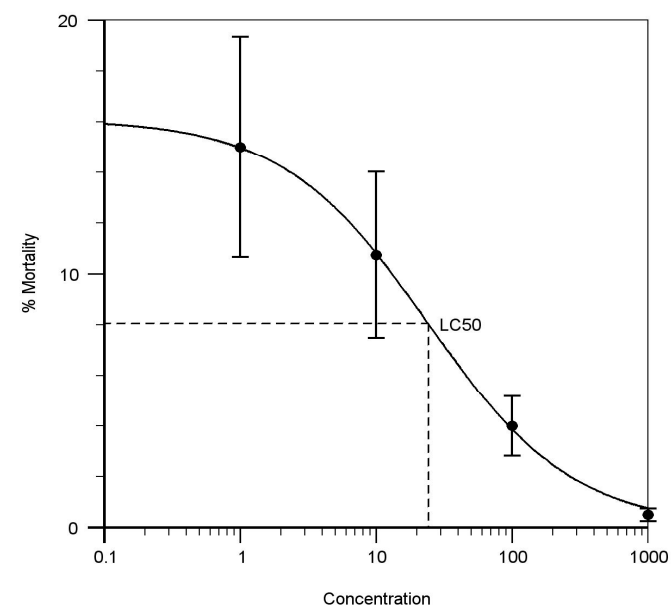

Figure 2. Cytotoxicity of Annona reticulata. (Alcoholic Extract).

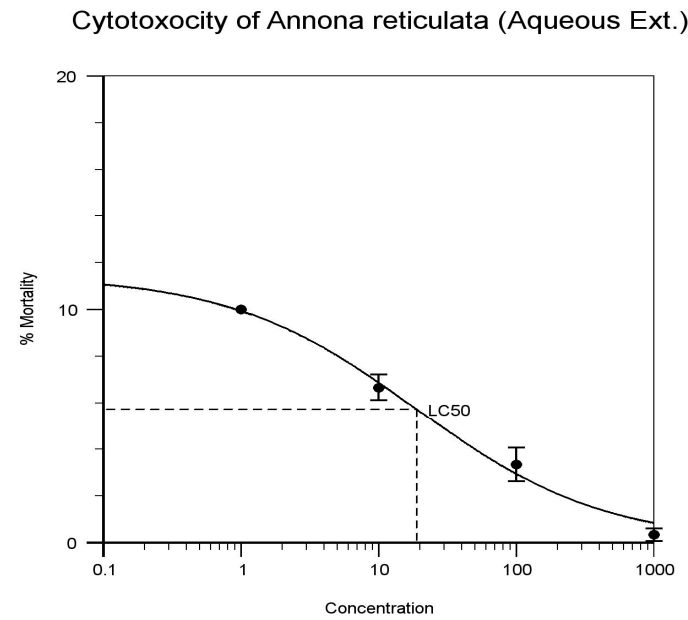

Figure 3. Annona reticulata. (Aqueous Extract).

Cytotoxocity of Allium sativum (Alcoholic Ext.)

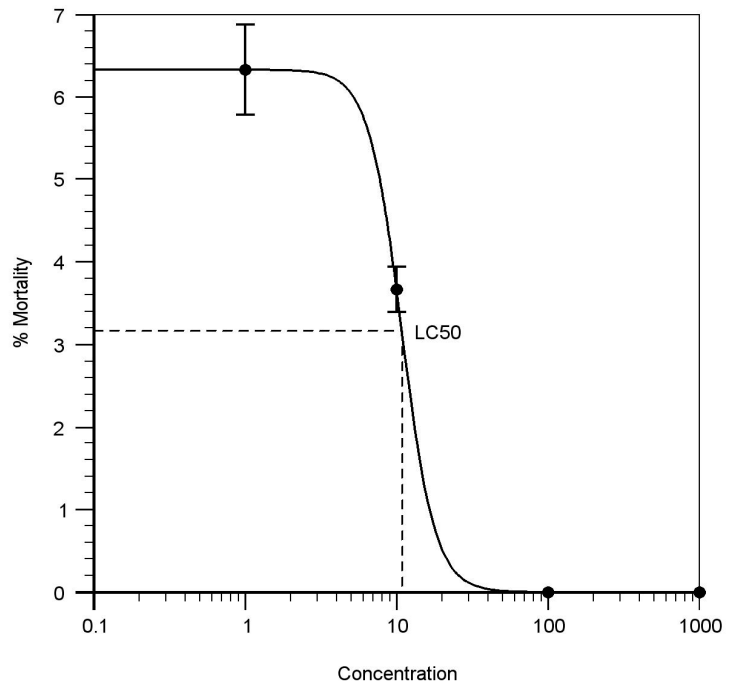

Figure 4. Allium sativum. (Alcoholic extract). 
Cytotoxocity of Allium sativum (Aqueous Ext.)

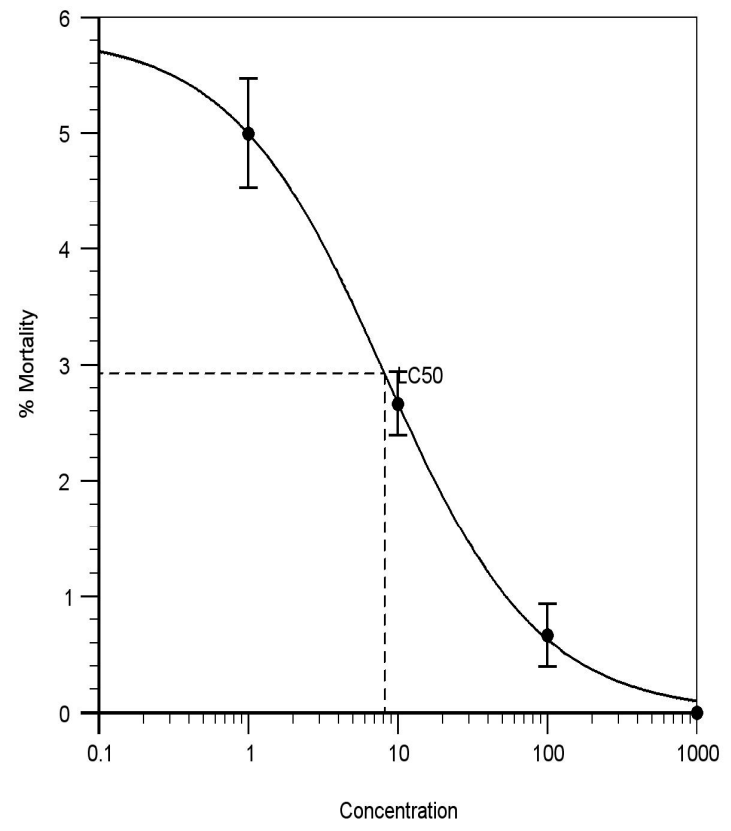

Figure 5. Allium sativum. (Aqueous extract).

Cytotoxocity of A. reticulate and A. sativum Alc.

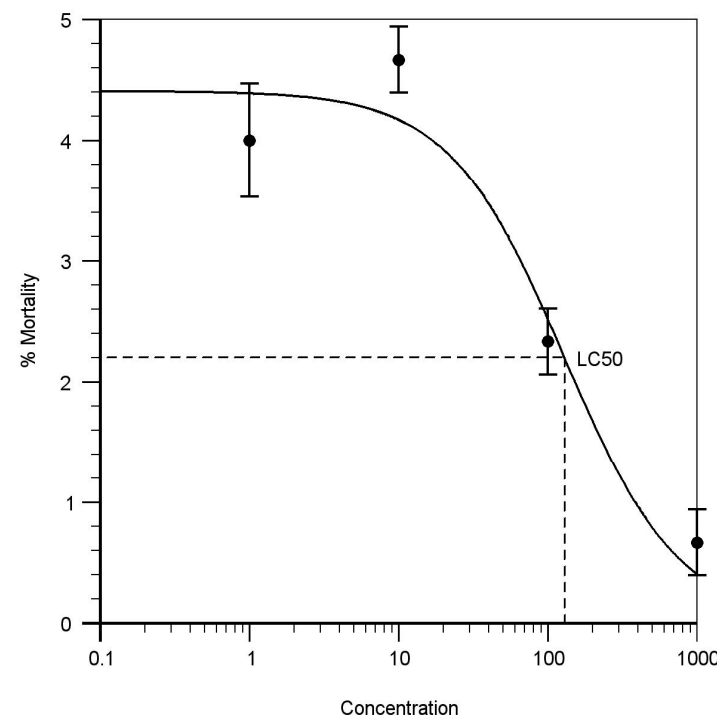

Figure 6. Annona reticulate and Allium sativum (1:1). Alcoholic extracts. 
Cytotoxocity of A. reticulate and A. sativum Aq.

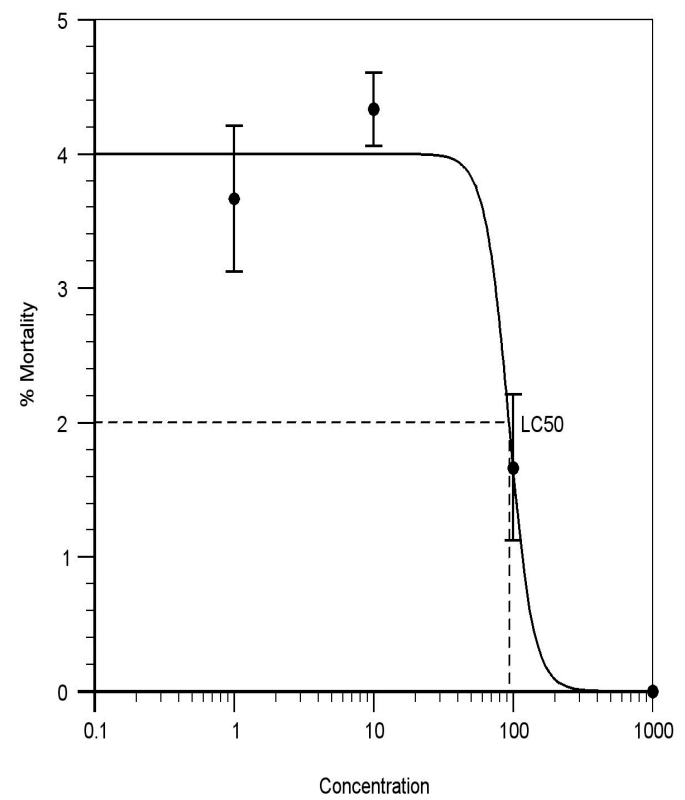

Figure 7. Annona reticulate and Allium sativum (1:1). Aqueous extracts.

\section{Result and Discussion}

The result on the lethality of Alcoholic and aqueous extract of Annona reticulate on brine shrimps is in agreement with other studies where its LC 50 values are $24.162 \mu \mathrm{g} / \mathrm{mL}$ and $18.923 \mu \mathrm{g} / \mathrm{mL}$ (as indicated in Figures 2 and 3). Alcoholic and aqueous extract bulbs of Allium sativum recorded LC 50 values of 10.840 and $8.180 \mathrm{mg} / \mathrm{mL}$ (as indicated in Figures 4 and 5) against brine shrimps. The presence of alkaloids, tannins, and flavonoids could be accounted for its cytotoxic properties. In the other hand, studies have shown that the leaf extracts of Alcoholic and aqueous extract of Annona reticulata and bulbs of Allium sativum extracts exhibited cumulative activity when they were combined and compared. Thus, the leaf extracts of Alcoholic and aqueous extract of Annona reticulata and bulbs of Allium sativum exhibited increase in activity support its use in traditional medicine.

\section{Conclusions}

The leaf extracts of Alcoholic and aqueous extract of Annona reticulata and bulbs of Allium sativum exhibited cytotoxic activity against the brine shrimp and considered as containing active or potent components. This is because their $\mathrm{LC}_{50}$ values are less than $1000 \mathrm{ppm}$ or $\mu \mathrm{g} / \mathrm{mL}$. Annona reticulate and Allium sativum (1:1) Alcoholic extracts shows LC 50 values $129.257 \mu \mathrm{g} / \mathrm{mL}$ and Annona reticulate and allium sativum (1:1) Aqueous extracts shows LC 50 values $93.482 \mu \mathrm{g} / \mathrm{mL}$ (as indicated in Figures 6 and 7). The Alcoholic and aqueous extract of Annona reticulata and bulbs of Allium sativum when combined in (1:1) proportions, the higher LC 50 values shows better cytotoxocity than single extracts. The ethnopharmacological activities of these plant species are due to the different bioactive compounds present in these plants. Although, BSLA is inadequate in determining the mechanism of action of the bioactive substances in the plant, it is very useful by providing a preliminary screen that can be supported by a more specific bioassay, once the active compound has been isolated. Thus, some useful drugs of therapeutic importance may develop out of the research work.

Acknowledgments: The present research work was thankful to Mohan kale, Principal, Bharat Tekade, HOD, Pharmacy Department and Amol Chadekar, HOD of the Pharmacology Department KGRDCP \& RI, Karjat. 


\section{References}

1. Malorni, W.; Rivabene, R.; Lucia, B.M.; Ferrara, R.; Mazzone, A.M.; Cauda, R.; Paganelli, R. The role of oxidative imbalance in progression to AIDS effect of the thiol supplier N-acetyl cysteine. AIDS Res. Hum. Retrovir. 1998, 14, 1589-1596.

2. Robert, A.; Meunier, B. Is alkylation the main mechanism of action of the antimalarial drug artemisinin? Chem. Soc. Rev. Artic. 1998, 27, 273-274.

3. Shah, PM. The need for new therapeutic agents: What is in the pipeline? Clin. Microbiol. Infect. 2005, 11, 36-42.

4. Da-Silva, J.F.M.; De-Souza, M.C.; Matta, S.R.; De-Andrade, M.R.; Vidal, F.V.N. Correlation analysis between phenolic levels of Brazilianpropolisextracts and their antimicrobial and antioxidant activities. Food Chem. 2006, 99, 431-435.

5. Majhenic, L.; Skerget, M.; Knez, Z. Antioxidant and antimicrobial activity of guarana seed extracts. Food Chem. 2007, 104, 1258-1268.

6. Pereira, J.A.; Oliveira, I.; Sousa, A.; Valentao, P.; Andrade, P.B. Walnut (Juglansregia L.) leaves: Phenolic compounds, antibacterial activity and antioxidant potential of different cultivars. Food Chem. Toxicol. 2007, $45,2287-2295$.

7. Rout Soumya, P.; Kar Durga, M.; Mohapatra Santosh, B.; Swain Sharada, P. Anti-hyperglycemic effect Annona reticulata L. Leaves on experimental diabetic rat model. Asian J. Pharm. Clin. Res. 2013, 6, 56-60.

8. Rout, S.P.; Kar, D.M. Identification of chemical compounds present in different fractions of Annona reticulata L. Leaf by using GC-MS. Nat. Prod. Res. 2014, 28, 1786-1788.

9. Rout, S.P.; Kar, D.M.; Maharana, L. Anti-Hyperglycemic Effect of different fractions of Annona Reticulata leaf. Asian J. Pharm. Clin. Res. 2016, 9, 256-262. doi:10.22159/ajpcr.2016.v9s2.13710.

10. Padjama, R.; Arun, P.C.; Prashanth, D.; Deepak, M.; Amit, A.; Anajna, M. Brine shrimp lethality bioassay of Indian medicinal plants. Fitoterapia 2002, 73, 508-510.

11. Abhilasha, S.; Kuntal, K. Analysis of phytochemical constituents and pharmacological properties of Abrus precatorius L. Int. J. Pharm. Biol. Sci.2013, 4, 91-96.

12. Adelowotan, O.; Aibinu, I.; Aednipekun, E.; Odugbemi, T. The in vitro antimicrobial activity of Abrus Precatorius (L) fabaceae extract on some clinical pathogens. Niger. Postgrad. Med. J. 2008, 15, 32-37.

13. Prashith Kekuda, T.R.; Vinayaka, K.S.; Soumya, K.V.; Ashwini, S.K.; Kiran, R. Antibacterial and antifungal activity of methanolic extract of Abrus pulchellus wall and Abrus precatorius Linn-a comparative study. Int. J. Toxicol. Pharm. Res. 2010, 2, 26-29.

14. Adedapo, A.A.; Omoloye, O.A.; Ohore, O.G. Studies on the toxicity of an aqueous extract of the leaves of Abrus precatorius in rats. Onderstepoort J. Vet. Res. 2007, 74, 31-36.

(C) 2019 by the authors. Licensee MDPI, Basel, Switzerland. This article is an open access article distributed under the terms and conditions of the Creative Commons Attribution (CC BY) license (http://creativecommons.org/licenses/by/4.0/). 